\title{
Dynamics of mineral nitrogen in the gray forest soil under malt barley on the background of mineral fertilizers in the forest steppe of the east Prisayan
}

\author{
Viktor Grebenshchikov ${ }^{1, *}$, Nikolay Tyutrin ${ }^{2}$, and Vasily Verkhoturov ${ }^{3}$ \\ ${ }^{1}$ Irkutsk State Agrarian University named after A.A. Ezhevsky, 664038 Irkutsk, Russia \\ ${ }^{2}$ Irkutsk national research technical University, 664074 Irkutsk, Russia \\ ${ }^{3}$ Kaliningrad State Technical University, 236022 Kaliningrad, Russia
}

\begin{abstract}
The content of mineral nitrogen was studied when it was applied at a dose of $60 \mathrm{~kg} /$ ha on gray forest soil of heavy particle- size distribution at various levels of phosphorus-potassium nutrition in field experiments with barley. Fertilizer doses were determined by the normative method according to the CINAS method for a planned yield of 3 $\mathrm{t} / \mathrm{ha}$. It was shown that the dynamics of nitrate and ammonium nitrogen depended on the moisture regime during the vegetation period. With excessive moisture, nitrate nitrogen, with its initial content of 4-5 mg / kg, is not detected in the arable layer by the middle of the growing season, and with a moisture deficit, less dynamism is noted. It is found in an amount of $5-7 \mathrm{mg} / \mathrm{kg}$ by the end of vegetation. The $\mathrm{N}-\mathrm{NH} 4+$ dynamics turned out to be less pronounced. With an excess of moisture, its content increased to $15.6 \mathrm{mg} / \mathrm{kg}$, and with a deficit, it decreased more than by four times from the maximum during the vegetation. In general, the content of mineral nitrogen in gray forest soil is highly dynamic, which depends on the moisture regime and the nature of its consumption by barley.
\end{abstract}

\section{Introduction}

Barley is one of the most important grain crops which is grown practically in all countries of the world [1] and used for producing various foodstuffs and forages [2]. The yielding capacity and quality of brewer's barley are influenced by soil and climatic conditions of growing, a pre-sown crop and the application of a fertilizer, and others [3].

The contemporary literature has collected a lot of data on the effect of nitrogenous fertilizers on the yield and quality of malting barley [4-6]. Excessive nitrogenous fertilizer increases the nitrogen content in vegetative parts, and then contributes to raising protein content of grain which worsens the brewing qualities of the crop. The application of a nitrogenous fertilizer prior to sowing for cultivation to a greater extent increases the yield of barley and, to a lesser extent - the protein content in grain than the application of this fertilizer in the form of top- dressing at the beginning of barley tillering phase.

\footnotetext{
*Corresponding author: biovervv@mail.ru
} 
Nitrogen plays an important role in the formation of the amount and quality of field crops yield, and under conditions of Pre-Sayan area it is in the first minimum, and the lack of it does not allow cultivated cereals to fully realize their varietal potential [7]. The demands of spring grains in nitrogen are compensated at the expense of soil reserves to the grain yield 1.1-1.5 t/ha, as well as with mineral fertilizers. In the European part of Russia, the applied nitrates are intensively lost as a result of denitrification and leaching out, at that the maximum migration of nitrates in black soils and other types of soils is observed at their high concentration. However, under conditions of Siberia, it is proved that there is no significant washout of mineral nitrogen from the root layer in the main types of soils [8].

In the Irkutsk region, gray forest soils are located mainly in the forest-steppe belt, where they receive up to $85 \%$ of the regional gross agricultural output and in the structure of agricultural land occupy 838.1 thousand hectares, or $47 \%$ of the regional arable land. However, their productivity remains relatively low, since the potential fertility of gray forest soils is limited by the content of mineral nitrogen on the background of a short vegetation period. In this regard, the application of mineral fertilizers, and primarily nitric ones, enables to raise the productivity of grain crops by $40-60 \%$.

The goal of the research was to study the dynamics of mineral nitrogen at different levels of phosphorus-potassium nutrition of barley supplying a high yield with good technological qualities of grain.

\section{Materials and methods}

The studies were conducted in the forest-steppe belt of Eastern Pre-Sayan area according to the scheme of a small-plot field trial in gray forest soil on a no-fallow predecessor (potatoes on a fallow) for three years. The technology of growing barley is typical for this zone of the Irkutsk region.

The rates of the applied nutritional elements were determined by the standard method for the planned yield $3 \mathrm{t} / \mathrm{ha}$ according to the CINAS method.

The location of the plots was consecutive. The area of the experimental plots was 9-18 $\mathrm{m}^{2}$, accounting ones $-4-8 \mathrm{~m}^{2}$. The replication was fourfold. The scheme of the trial is given below:

1. Without fertilizers (the control);

2. $\mathrm{N}_{60} \mathrm{P}_{30} \mathrm{~K}_{60}$ - fertilizer rate for the planned yield $3 \mathrm{t} / \mathrm{ha}$;

3. $\mathrm{N}_{60} \mathrm{P}_{45} \mathrm{~K}^{60}$ - fertilizer rate with increased level of $\mathrm{P}_{2} \mathrm{O}_{5}$;

4. $\mathrm{N}_{60} \mathrm{P}_{30} \mathrm{~K}^{90}$ - fertilizer rate with increased level of $\mathrm{K}_{2} \mathrm{O}$;

5. $\mathrm{N}_{60} \mathrm{P}_{45} \mathrm{~K}^{90}$ - fertilizer rate determined by the standard method for the planned yield 3 t/ha, with a 1.5-dose of $\mathrm{P}_{2} \mathrm{O}_{5}$ and $\mathrm{K}_{2} \mathrm{O}$.

The $50 \%$ increase from the standard level of phosphorus and potassium fertilizers application of was conditioned by the fact that the literature has marked a positive effect of increased background of $\mathrm{P}_{2} \mathrm{O}_{5}$ and $\mathrm{K}_{2} \mathrm{O}$ on the brewing quality of barley grain. Annually fertilizers were applied in spring for pre-sowing cultivation. Ammonium nitrate, double superphosphate, and potassium chloride were used as fertilizers.

The soil of the test field was characterized by an average acidic reaction of the medium ( $\mathrm{pH} 4.8-4.9)$, a low reserve of mineral nitrogen (8-10 $\mathrm{mg} / \mathrm{kg}$ ) and exchangeable potassium (60-70 mg/kg), a high supply of labile phosphorus $(225-283 \mathrm{mg} / \mathrm{kg}$ ) with a humus content 1.6-2.0\%. According to the granulometric composition, the soil is heavy loamy, formed on loessial loams.

The conditions of heat and moisture supply of the crop during the research period differed both in years and in their distribution by development phases. The average annual precipitation during the growing season of the crop was $269 \mathrm{~mm}$, the hydrothermal coefficient (further - HTC) according to Selyaninov was 1.48. At the same time, in a wet 
year, $359.2 \mathrm{~mm}$, or $137 \%$ of the standard, fell (HTC 2.16), in a dry year - $250.9 \mathrm{~mm}$, or $90.7 \%$ of the standard (HTC 1.33). One year of observations on the parameter of heat and moisture supply was at the level of the average long-term values.

The observations have shown that in initial period of growth in most years, barley developed with insufficient moisture (HTC 0.84-1.30), and according to atmospheric precipitation, even in arid conditions. By the time of the crop flowering, the indicators of heat and moisture supply were improving, the barley plants developed in moderate-humid conditions (HTC 1.3-2.0). On the whole, according to meteorological conditions, there was an uneven distribution of precipitation during the vegetation period and the presence of insufficient moisture in the initial phases of growth and development.

The studies were carried out with a zoned mid-ripening variety of two-rowed barley Odessa 115 for brewing purposes. Soil samples were taken in three sites of a plot from a depth $0-20$ and $20-40 \mathrm{~cm}$ in the main phases of barley development. The agrochemical analysis of the soil was carried out according to the commonly accepted methods recommended by the zonal agrochemical laboratory for gray forest soils (phosphorus and potassium were determined on GOST 26207-91).

\section{Results and discussion}

In the fertilized variants the supply of nitrogen background thanks to ammonium nitrate increases the content of $\mathrm{NH}_{4}$ and $\mathrm{NO}_{3}$ in the soil. During the period of barley growth and development, the concentration of these elements in the soil between the fertilized variants and the control was equalized, especially in terms of $\mathrm{NH}_{4}$ content, both due to its lower lability and more intensive nitrogen uptake by plants.

In the control (without fertilizers) the soil contained $5.6-7.5 \mathrm{mg} / \mathrm{kg} \mathrm{N}-\mathrm{NH}_{4}$ by the time of seeding. At tillering stage the content of $\mathrm{N}-\mathrm{NH}_{4}$ in the soil rose both due to nitrogenous fertilizers, and microbiological activity. Later, the dynamics of $\mathrm{N}-\mathrm{NH}_{4}$ and $\mathrm{NO}_{3}$ for the growing season largely depended on the moisture conditions and differed significantly (table 1).

In a relatively dry year (227 $\mathrm{mm}$ of precipitation for the vegetation period), there was a decline in ammonia nitrogen, while under conditions of excessive humidification (343 mm for the growing season), the amount of ammonium nitrogen increased. In our opinion, this occurred due to the fact that in initial stages of growth and development the plants used nitrate nitrogen $\left(\mathrm{N}-\mathrm{NO}_{3}\right)$, which was found at flowering and harvesting stages in the form of traces.

Essential differences in the content of ammonium and nitrates during the growing season in the years of observations were obviously caused by different moisture regimes and related microbiological processes for mineralization of labile organic matter in the soil. Under conditions of excessive humidification, nitrification processes in the soil of heavy granulometric composition were suppressed, and by the mid-vegetation of barley only N$\mathrm{NO}_{3}$ traces were found. This is explained by the uptake of nitrate nitrogen by barley on the background of worse conditions for nitrification in the soil.

Under conditions of moisture deficiency during the first half of the growing season (HTC 0.84), the tillering phase at high air temperatures passed rapidly. A relatively small assimilation apparatus of plants was formed, which reduced the intensity and amount of nitrogen absorption in this period. Later, by the time of flowering, the conditions of moisture supply improved, which is typical for Pre-Sayan zone and there was a sharp absorption of nitrate nitrogen, and in case of excessive moisture, only traces of it are found. 
Table 1. Dynamics of ammonia and nitrate nitrogen content in soil by development phases depending on humidification conditions (mg/kg).

\begin{tabular}{|c|c|c|c|c|c|c|c|c|c|c|}
\hline \multirow{2}{*}{$\begin{array}{l}\text { Va- } \\
\text { ria- } \\
\text { nt }\end{array}$} & \multirow[t]{2}{*}{$\begin{array}{l}\text { Depth, } \\
\text { cm. }\end{array}$} & \multicolumn{3}{|c|}{ Insufficient humidification } & \multicolumn{3}{|c|}{$\begin{array}{l}\text { Long-term average } \\
\text { humidification }\end{array}$} & \multicolumn{3}{|c|}{ Excessive humidification } \\
\hline & & $\begin{array}{c}\text { tillerin } \\
\mathrm{g}\end{array}$ & flowering & $\begin{array}{c}\text { wax } \\
\text { ripenes } \\
\mathrm{s}\end{array}$ & $\begin{array}{c}\text { tillerin } \\
\mathrm{g}\end{array}$ & $\begin{array}{c}\text { floweri } \\
\text { ng }\end{array}$ & $\begin{array}{c}\text { wax } \\
\text { ripenes } \\
\mathrm{s}\end{array}$ & $\begin{array}{c}\text { tillerin } \\
\mathrm{g}\end{array}$ & $\begin{array}{c}\text { floweri } \\
\text { ng }\end{array}$ & $\begin{array}{c}\text { wax } \\
\text { ripenes } \\
\mathrm{s}\end{array}$ \\
\hline \multicolumn{11}{|c|}{ Ammonia nitrogen content } \\
\hline \multirow[t]{2}{*}{1} & $0-20$ & 10.5 & 7.5 & 4.3 & 8.5 & 9.0 & 4.8 & 6.3 & 10.5 & 5.2 \\
\hline & $20-40$ & 7.8 & 6.4 & 3.8 & 6.4 & 10.1 & 6.5 & 4.8 & 13.4 & 9.1 \\
\hline \multirow[t]{2}{*}{2} & $0-20$ & 8.5 & 7.6 & 4.7 & 7.6 & 10.3 & 6.0 & 6.4 & 13.0 & 7.7 \\
\hline & $20-40$ & 5.5 & 6.2 & 3.9 & 5.4 & 11.0 & 6.2 & 5.2 & 15.6 & 8.8 \\
\hline \multirow[t]{2}{*}{3} & $0-20$ & 9.4 & 8.1 & 4.5 & 8.5 & 10.2 & 6.1 & 7.6 & 12.6 & 8.0 \\
\hline & $20-40$ & 8.1 & 6.8 & 4.0 & 8.0 & 9.5 & 5.9 & 7.8 & 12.4 & 8.0 \\
\hline \multirow[t]{2}{*}{4} & $0-20$ & 7.8 & 7.8 & 3.8 & 7.6 & 9.9 & 7.4 & 7.4 & 11.6 & 11.0 \\
\hline & $20-40$ & 8.0 & 8.0 & 4.0 & 7.2 & 11.0 & 7.3 & 6.3 & 14.0 & 10.7 \\
\hline \multirow[t]{2}{*}{5} & $0-20$ & 9.2 & 7.5 & 4.1 & 7.6 & 9.0 & 6.8 & 6.0 & 10.3 & 9.3 \\
\hline & $20-40$ & 9.4 & 7.7 & 4.1 & 8.2 & 10.0 & 7.0 & 7.0 & 12.4 & 10.3 \\
\hline \multicolumn{11}{|c|}{ Nitrate nitrogen content } \\
\hline \multirow[t]{2}{*}{1} & $0-20$ & 12.3 & 3.9 & 1.7 & 8.6 & 4.0 & 2.0 & 4.8 & - & - \\
\hline & $20-40$ & 12.0 & 3.9 & 2.1 & 7.8 & 4.0 & 2.1 & 3.5 & - & - \\
\hline \multirow[t]{2}{*}{2} & $0-20$ & 13.8 & 2.7 & 4.2 & 12.0 & 2.9 & 4.3 & 10.2 & - & - \\
\hline & $20-40$ & 20.0 & 3.1 & 5.0 & 13.0 & 3.2 & 5.0 & 6.1 & - & - \\
\hline \multirow[t]{2}{*}{3} & $0-20$ & 17.4 & 1.2 & 4.8 & 13.2 & 1.5 & 4.9 & 9.0 & - & - \\
\hline & $20-40$ & 19.5 & 4.4 & 5.5 & 13.0 & 4.5 & 5.5 & 6.4 & - & - \\
\hline \multirow[t]{2}{*}{4} & $0-20$ & 19.5 & 5.5 & 6.1 & 15.5 & 5.5 & 6.1 & 14.1 & - & - \\
\hline & $20-40$ & 15.5 & 2.7 & 4.2 & 11.8 & 2.8 & 4.1 & 8.2 & - & - \\
\hline \multirow[t]{2}{*}{5} & $0-20$ & 17.4 & 1.7 & 3.1 & 15.7 & 1.5 & 3.1 & 14.0 & - & - \\
\hline & $20-40$ & 15.5 & 3.5 & 4.8 & 11.8 & 3.6 & 4.8 & 7.9 & - & - \\
\hline
\end{tabular}

As we suppose, the relatively high content of $\mathrm{N}^{-\mathrm{NH}_{4}}{ }^{+}$in the soil in the non-fertilized variant compared to the variant with fertilizers with insufficient moisture was caused by the fact that with additional phosphorus nutrition and a lack of moisture in the fertilized variants, the plants formed a more powerful root system than in the control. More active growth of roots and vegetative mass in the variants with fertilizers provided intensive nitrogen absorption, which reduced its concentration in the soil. However, the amount of mineral nitrogen at the flowering stage in the fertilized options and in the control was equal being at the level of $10-14 \mathrm{mg} / \mathrm{kg}$. The content of mineral nitrogen was determined by its initial content in the soil, the level of nitrogen applied, the intensity of its uptake by plants and hydrothermal conditions. Under conditions of insufficient moisture, the total content of ammonia and nitrate nitrogen during tillering was at the range of $20-28 \mathrm{mg} / \mathrm{kg}$ of soil, while with sufficient and excessive humidification its actual content was 1,5-2,0 times lower. 
Especially a sharp decrease in the content of mineral nitrogen was in the option without fertilizers. During the period of flowering-wax ripeness of barley, the differences in the content of mineral nitrogen were less distinguished both in the variants and in the conditions of moistening, and were within the range of $8.5-13.0 \mathrm{mg} / \mathrm{kg}$ of soil, which was caused by reducing rate of nitrogen absorption by plants on the background of its progressive mineralization from the labile organic matter of the soil. The relatively low content of mineral nitrogen in the non-fertilized option $5-10 \mathrm{mg} / \mathrm{kg}$ of soil is typical for this soil under conditions of the region.

Mathematical analysis has shown that there is a close inverse correlation between the content of ammonia and nitrate nitrogen at the flowering stage of barley $(r=-0.67 \ldots-0.76)$. In the variant with an increased application of $\mathrm{P}_{2} \mathrm{O}_{5}$ and $\mathrm{K}_{2} \mathrm{O}$, we obtained the grain that meets the requirements of the brewing industry in case of the yield at the level of the planned value.

\section{Conclusion}

The application of nitrogenous fertilizers under barley led to increasing $\mathrm{N}_{-} \mathrm{NO}_{3}, \mathrm{~N}_{-} \mathrm{NH}_{4}$ in gray forest soil. The dynamics of nitrate and ammonia nitrogen depended on a regime of humidification of the vegetation period. At the initial content of nitrate nitrogen at the range of $12 \mathrm{mg} / \mathrm{kg}$ in the arable layer by mid-summer, with excessive moisture, nitrates are not detected. With a lack of moisture, the dynamics of nitrates was less distinguished, its content ranged in the amount from 5 to $7 \mathrm{mg} / \mathrm{kg}$ by the end of the growing season. The dynamics of $\mathrm{N}-\mathrm{NH}_{4}{ }^{+}$had the features differing from that of nitrate nitrogen. In case of excessive humidification, its content rose at three times from the initial one - since 4.8 to $15.5 \mathrm{mg} / \mathrm{kg}$, and with lack of it - reduced more than at 4 times and till the end of crop vegetation accounted 4 against $18 \mathrm{mg} / \mathrm{kg}$ of a maximum value. Increased background of phosphorus and potassium nutrition did not have a significant impact on the dynamics of mineral nitrogen, but contributed to a more active uptake of nutrients from the soil and providing conditions for the production of malting barley.

\section{References}

1. I.K. Dawson, J. Russell, W. Powell, B. Steffenson, W.T.B. Thomas, R. New Phytol., 206 (3), 913-931 (2015)

2. A.C. Newton, A.J. Flavell, T.S. George, P. Leat, B. Mullholland, L. Ramsay, et al. Food Security, 3 (2), 141 (2011)

3. L.Holm, A.H.Malik, E.Johansson J. of Cereal Science. 82, 230-242J (2018)

4. W. E. Baethgen, C. B. Christianson, A.G. Lamothe. Crops Research 43(2-3), 87-99 (1995).

5. D. Beillouin, R. Trépos, A. Gauffreteau, M-H. Jeuffroy. European J. of Agronomy. 101, 174-182 (2018).

6. S.P. Kennedy, J.P. Lynch, J. Spink, I.J. Bingham. Field Crops Research. 225, 74-82 (2018).

7. V.Yu. Grebenshchikov, V.S. Kopylova, N.O. Tyutrin, V.V. Verkhoturov. IOP Conference Series: Earth and Environmental Science, 548(2), 022105 (2020).

8. L.V. Budazhapov. Biosciences Biotechnology Research Asia, 1, 287-293 (2015). 